\title{
Beban dengan Koping Keluarga Saat Merawat Pasien Skizofrenia yang Mengalami Perilaku Kekerasan
}

\section{Burden with Koping Family when Treating Schizophrenia Patients with Violent Behaviour}

\author{
Jek Amidos Pardede ${ }^{1}$, Laura Mariati Siregar ${ }^{2}$, Merius Halawa ${ }^{3}$ \\ Program Studi Ners, Universitas Sari Mutiara, Indonesia
}

\section{ARTICLE INFO}

\section{Article history}

Received date

03 Auguts 2020

Revised date

06 August 2020

Accepted date

15 August 2020

Keywords:

Burden,

Family coping,

Schizophrenia,

Violent behavior.

\section{Kata kunci:}

Beban,

Koping keluarga,

Skizofrenia,

Perilaku kekerasan.

\begin{abstract}
ABSTRAK
Schizophrenia is a severe mental disorder that is chronic, reality disorders, cognitive dysfunction, and difficulty in doing activities. Violent behavior is a form of aggressive behavior that causes suffering or hurts others, has an angry response, is expressed by threatening, injuring oneself and others, and can damage the environment. The study aims to determine the relationship of burden with a family coping when treating schizophrenic patients who experience violent behavior in the Prof.Dr.M.Ildrem mental hospital Medan. Descriptive correlation research design with a cross-sectional approach. The entire population of schizophrenic patients who treat family members with violent behavior who undergo outpatient as many as 384 people. Samples totaling 79 people with a sampling technique is a consecutive sampling. The results obtained that the objective burden of the majority family is $74,7 \%$ and the subjective burden of the majority family is $60,8 \%$, coping of the adaptive majority family is $97,5 \%$. It is known that there is a strong relationship between burden and family coping when treating patients with schizophrenia who experience violent behavior ( $\mathrm{p}$-value $=0,000$; $\mathrm{p}$-value $<0,01$ ) with an objective load value of the correlation coefficient $(r)=0,522$. And the subjective load coefficient correlation coefficient $(r)=0,525$. Families are expected to reduce objective and subjective burdens when treating schizophrenic patients who experience violent behavior by increasing adaptive family coping so that the burden in the family is lighter and able to care for family members better.
\end{abstract}

Skizofrenia merupakan gangguan jiwa berat yang bersifat kronis, gangguan realitas, gangguan fungsi kognitif serta kesulitan dalam melakukan aktivitas. Perilaku kekerasan merupakan bentuk perilaku agresif yang menyebabkan penderitaan atau menyakiti orang lain, mempunyai respon marah, diekspresikan dengan melakukan ancaman, mencederai diri sendiri maupun orang lain dan dapat merusak lingkungan sekitar. Penelitian bertujuan mengetahui hubungan beban dengan koping keluarga saat merawat pasien skizofrenia yang mengalami perilaku kekerasan di rumah sakit jiwa Prof.Dr.Muhammad Ildrem Medan. Desain penelitian deskriptif korelasi dengan pendekatan cross sectional. Populasi seluruh keluarga pasien skizofrenia yang merawat anggota keluarga dengan perilaku kekerasan yang menjalani rawat jalan sebanyak 384 orang. Sampel berjumlah 79 orang dengan tekhnik pengambilan sampel adalah concecutive sampling. Hasil yang diperoleh bahwa beban obyektif keluarga mayoritas sedang $74,7 \%$ dan beban subyektif keluarga mayoritas sedang 60,8\%, koping keluarga mayoritas adaptif 97,5\%. Diketahui bahwa ada hubungan yang kuat antara beban dengan koping keluarga saat merawat pasiens kizofrenia yang mengalami perilaku kekerasan ( $p$-value $=0,000 ; p$-value $<0,01)$ dengan nilai beban obyektif correlation coefficient $(\mathrm{r})=0,522$. Dan nilai beban subyektif correlation coefficient $(r)=0,525$. Keluarga diharapkan dapat mengurangi beban obyektif dan subyektif saat merawat pasien skizofrenia yang megalami perilaku kekerasan dengan meningkatkan koping keluarga yang adaptif, sehingga beban dalam keluarga lebih ringan dan mampu merawat anggota keluarga lebih baik.

Corresponding Author:

Jek Amidos Pardede

Program Studi Ners, Universitas Sari Mutiara, Indonesia

Email: jekpardedemi@ rocketmail.com 


\section{PENDAHULUAN}

Skizofrenia merupakan gangguan mental berat dan kronis yang menyerang 20 juta orang di seluruh dunia (WHO, 2019). Sedangkan di Indonesia berdasarkan hasil Riskesdas (2018) didapatkan estimasi prevalensi orang yang pernah menderita skizofrenia di Indonesia sebesar 1,8 per 1000 penduduk. Data Riskesdas (2018) prevalensi skizofrenia Sumatera Utara sebanyak 13.991 orang (Kementerian Kesehatan RI, 2018). Skizofrenia menimbulkan distorsi pikiran sehingga pikiran itu menjadi sangat aneh, juga distorsi persepsi, emosi, dan tingkah laku yang dapat mengarah ke perilaku kekerasan yang dapat berbahaya dengan diri sendiri maupun orang lain sekitar (Benson, et al., 2013). Perilaku kekerasan merupakan salah satu respon terhadap stressor yang dihadapi oleh seseorang. Respon ini dapat menimbulkan kerugian baik kepada diri sendiri, orang lain, maupun lingkungan. Berdasarkan data Nasional Indonesia tahun 2017 dengan risiko perilaku kekerasan sekitar $0,8 \%$ atau dari 10.000 orang (Pardede, dkk., 2020).

Seseorang yang mengalami perilaku kekerasan sering menunjukkan perubahan perilaku seperti intonasi suara keras, mengancam, ekspresi tegang, gaduh, gelisah, tidak bisa diam, mondar-mandir, agresif, bicara dengan semangat, nada suara tinggi dan gembira berlebihan. Kekacauan alam fikir juga dapat dilihat dari isi pembicaraannya. Perubahan lain yang terjadi adalah adanya penurunan kemampuan memecahkan masalah, orientasi terhadap waktu, tempat, dan orang, serta gelisah (Stuart, 2014).

Risiko mencederai merupakan suatu tindakan yang kemungkinan dapat melukai atau membahayakan diri sendiri, orang lain, dan lingkungan sehingga masalah yang terjadi pada pasien perilaku kekerasan akan melibatkan keluarga. Menurut Suryenti (2017). Pasien skizofrenia terutama yang mengalami perilaku kekerasan membutuhkan dukungan keluarga yang mampu memberikan perawatan secara optimal, tetapi keluarga sebagai sistem pendukung utama sering mengalami beban yang tidak ringan dalam memberikan perawatan selama pasien dirawat di rumah sakit maupun setelah kembali ke rumah.

Keluarga merupakan orang terdekat dengan klien, dimana yang bertanggung jawab untuk merawat klien, namun dalam pelaksanaanya menjadi beban bagi keluarga baik beban obyektif maupun beban subyektif. Beban obyektif merupakan beban hambatan yang dialami keluarga seperti masalah dalam keluarga, pembatasan aktivitas sosial, stigma yang dialami keluarga dari masyarakat, dan beban ekonomi atau kesulitan keuangan untuk berobat. Sedangkan beban subyektif merupakan beban yang dialami anggota keluarga seperti frustasi, depresi, ansientas, ketidakberdayaan dan keputusasaan. Menurut Mantovani, et al (2016). beban keluarga terdiri dari dua subdomain yang berbeda namun saling melengkapi. Beban keluarga yang obyektif mengacu pada konsekuensi perawatan yang dapat diamati, seperti gangguan pada rutinitas keluarga yang dipicu oleh penyakit. Subdomain subyektif menunjuk pada beban emosional perawatan, seperti perasaan bersalah, dan kekhawatiran tentang masa depan. Tingkat beban yang berbeda dapat ditemukan di seluruh keluarga, tergantung pada pasien, pengasuh atau gambaran lingkungan.

Kondisi ini dapat menyebabkan meningkatnya stres emosional dan ekonomi dari keluarga sebagai efek dari kondisi anggota keluarganya sehingga keluarga memerlukan pengetahuan dan informasi bagaimana cara menghadapi anggota keluarga yang mengalami perilaku kekerasan dan untuk memperkecil dampak yang ditimbulkan, dibutuhkan penanganan perilaku kekerasan yang tepat keluarga memiliki peran yang sangat penting untuk mencegah kejadian yang tidak diinginkan dengan menggunakan ketrampilan koping untuk menghadapi masalah (Townsend \& Morgan, 2017). Keluarga yang merawat pasien skizofrenia juga akan mengalami kualitas hidup yang tidak baik karena terbebani oleh anggota keluarga yang sakit (Nuttall, 2019). Menurut Jenkins \& Schumacher (2018). Keluarga yang terbebani dengan pasien skizofrenia terkadang mengalami depresi karena tidak menggunakan koping dengan baik. Tetapi keluarga yang mampu merawat pasien skizofrenia adalah keterampilan praktis yang memungkinkan orang dewasa dengan keadaan tertentu mencapai kehidupan yang mandiri dan menyenangkan (Patricia, et al., 2019).

Koping keluarga merupakan cara untuk menghadapi atau menangani masalah-masalah yang ditemukan terkait dengan perawatan anggota keluarga serta mengurangi stres pada keluarga. Koping keluarga juga merupakan sebagai respon positif yang sesuai dengan masalahnya secara efektif, persepsi, dan perilaku yang digunakan oleh keluarga. Sedangkan masalah koping keluarga dikatakan respon perilaku, kognitif dan emosional keluarga yang diartikan sebagai masalah atau situasi khusus. Perbedaan situasi dan masalah membutuhkan pemecahan yang berbeda, seperti respon koping 
yang berbeda yang perlu diterapkan sumbersumber koping keluarga secara eksternal yang berhubungan dengan penggunaan sistem pendukung sosial oleh keluarga. Sehingga keluarga yang merawat penderita gangguan jiwa memerlukan koping yang adaptif (Friedman, 2013).

Berdasarkan data yang didapatkan dari RSJ Prof. M. Ildrem Provsu Medan tahun 2018 total pasien 4.341 orang dan yang mengalami risiko perilaku kekerasan sebanyak 3,6\% (155 orang) dari total keseluruhannya. Hasil wawancara dari keluarga bahwa ada keluarga mengeluhkan dan terbebani dengan kondisi anggota keluarga mereka pada saat ini. Mereka mengatakan sudah capek dan tidak fokus dalam melakukan pekerjaan berhubung karena merawat anggota keluarga yang sedang sakit. Keluarga mengatakan materi yang dikeluarkan sudah melebihi batas kemampuan mereka. Ada juga keluarga mengatakan sudah tidak mampu untuk merawat anggota keluarga yang sedang sakit dikarenakan perilaku yang sering dilakukan oleh anggota keluarga yang sakit, seperti marah apabila tidak terpenuhi apa yang dia minta, sering marah-marah dirumah dan bahkan memukul anggota keluarga lainnya. Keluarga juga mengatakan sudah jerah membawa anggota keluarga untuk berobat, mulai dari orang pintar sampai ke rumah sakit dan mereka merasa bahwa penyakitnya tidak dapat disembuhkan lagi. Bahkan keluarga juga mengatakan kepada perawat untuk dirawat di rumah sakit saja.

Sehingga peneliti tertarik untuk meneliti tentang beban dengan koping keluarga saat merawat pasien yang mengalami perilaku kekerasan yang bertujuan untuk mengidentifikasi beban subjektif dan objektif keluarga yang dirasakan dengan koping yang digunakan saat merawat pasien skizofrenia.

\section{METODE}

Desain penelitian ini adalah deskriptif korelasi dengan menggunakan pendekatan CrossSectional.Populasi yang digunakan yaitu seluruh keluarga pasien skizofrenia yang merawat anggota keluarga dengan perilaku kekerasan yang menjalani rawat jalan di Poliklinik Rumah Sakit Jiwa Prof.Dr.Muhammad Ildrem Provsu Medan Tahun 2018. Sampel dalam penelitian ini berjumlah 79 orang. Teknik pengambilan sampel yang digunakan dalam penelitian ini adalah concecutive sampling.

Penelitan ini menggunakan alat ukur kuesioner untuk mengukur beban obyektif dan subyektif keluarga yang telah di uji validitas dan reliabilitas sebanyak 15 pernyataan dengan croanbach's alfa 0,658 dan kuesioner mengukur koping keluarga sebanyak 14 pernyataan dengan croanbach's alfa 0,908. Sebelum kuesioner diberikan pada responden terlebih dahulu peneliti minta persetujuan responden. Data yang telah terkumpul akan dianalisis menggunakan uji statistik Spearman-Rho dengan $p$-value $<0,01$ dengan tingkat signifikansi $90 \%$.

Penelitian ini telah melewati kaji etik dan memperoleh Keterangan Lolos Kaji Etik (Ethical Approval) dengan Nomor 348/KEPK/FKUMSU/2018 oleh Komisi Etik Penelitian Kesehatan Fakultas Kedokteran Universitas Muhammadiyah Sumatera Utara.

\section{HASIL}

Tabel 1. Distribusi Frekuensi dan Persentase Karakteristik Responden yang Merawat Pasien yang Mengalami Perilaku Kekerasan

\begin{tabular}{lrr}
\hline \multicolumn{2}{c}{ Karakteristik } & \multicolumn{1}{c}{$\%$} \\
\hline Usia (Tahun) & 4 & 5,1 \\
\hline $20-30$ & 42 & 53,2 \\
$31-50$ & 33 & 41,8 \\
$51-60$ & & \\
\hline Jenis Kelamin & 46 & 58,2 \\
\hline Laki-laki & 33 & 41,8 \\
Perempuan & & \\
\hline Pendidikan & 8 & 10,1 \\
\hline Tidak Sekolah & 6 & 7,6 \\
SD & 22 & 27,8 \\
SMP & 26 & 32,9 \\
SMA & 17 & 21,5 \\
Perguruan Tinggi & & \\
\hline Pekerjaan & 14 & 17,7 \\
\hline PNS & 25 & 31,6 \\
Petani & 37 & 46,8 \\
Wiraswasta & 3 & 3,8 \\
Tidak bekerja & \\
\hline Hubungan dengan Pasien & & \\
\hline Ayah & 28 & 35,4 \\
Ibu & 23 & 29,1 \\
Saudara Kandung & 28 & 35,4 \\
\hline & &
\end{tabular}

Berdasarkan tabel 1 dapat dilihat bahwa usia responden mayoritas rentang 31-50 tahun sebesar 53,2\%, Jenis kelamin mayoritas adalah Laki-lakisebesar 58,2\%, Pendidikan mayoritas SMA sebesar 32,9\%, Pekerjaan mayoritas wiraswasta sebesar $46,8 \%$ dan hubungan dengan pasien adalah ayah sebsar $35,4 \%$ dan saudara kandung sebesar $35,4 \%$. 
Tabel 2. Beban Objektif dan Subjektif Keluarga Saat Merawat Pasien yang Mengalami Perilaku Kekerasan

\begin{tabular}{lrr}
\hline Beban Objektif & \multicolumn{1}{c}{$\mathrm{n}$} & \multicolumn{1}{c}{$\%$} \\
\hline Ringan & 10 & 12,7 \\
Sedang & 59 & 74,7 \\
Bearat & 10 & 12,7 \\
\hline Beban Subjektif & & \\
Ringan & 6 & 7,6 \\
Sedang & 48 & 60,8 \\
Berat & 25 & 31,6 \\
\hline
\end{tabular}

Berdasarkan tabel 2 dapat dilihat bahwa beban obyektif keluarga mayoritas sedang sebesar $74,7 \%$ dan beban subyektif keluarga saat merawat pasien perilaku kekerasan mayoritas sedang sebesar $60,8 \%$.

Tabel 3. Distribusi Frekuensi dan Persentase Koping Keluarga Saat Merawat Pasien Skizofrenia yang Mengalami Perilaku Kekerasan

\begin{tabular}{crr}
\hline Koping Keluarga & \multicolumn{1}{c}{ n } & \multicolumn{1}{c}{$\%$} \\
\hline Adaptif & 77 & 97,5 \\
\hline Maladaptif & 2 & 2,5 \\
\hline
\end{tabular}

Berdasarkan tabel 3 dapat dilihat bahwa mayoritas koping keluarga saat merawat pasien perilaku kekerasan mayoritas adaptif sebesar $97,5 \%$.

Tabel 4. Hubungan Beban Objektif Dengan Koping Keluarga Saat Merawat Pasien Perilaku Kekerasan

\begin{tabular}{lc}
\hline & Koping Keluarga \\
\hline Beban Objektif & $r=0,522 \quad p<0.000$ \\
\hline
\end{tabular}

Hasil uji statistik dapat diketahui nilai $p$ value $=0,000 ; \quad p$-value $<0,01 \quad$ dengan nilai correlation coefficient $(r)=0,522$ dengan menggunakan Spearman-rho terdapat ada hubungan yang kuat antara beban objektif keluarga dengan koping keluarga yang artinya semakin ringan beban objektif keluarga semakin adaptif koping keluarga.

Tabel 5. Hubungan Beban Subjektif Dengan Koping Keluarga Saat Merawat Pasien Perilaku Kekerasan

\begin{tabular}{lc}
\hline & Koping Keluarga \\
\hline Beban Subjektif & $r=0,525 p<0.000$ \\
\hline
\end{tabular}

Hasil uji statistik dapat diketahui nilai pvalue $=0,000 ; \quad p$-value $<0,01$ dengan nilai correlation coefficient $(r)=0,525$ dengan menggunakan Spearman-rho terdapat ada hubungan yang kuat antara beban subjektif keluarga dengan koping keluarga yang artinya semakin ringan beban subjektif keluarga semakin adaptif koping keluarga.

\section{PEMBAHASAN}

\section{Beban Objektif Keluarga Saat Merawat Pasien Skizofrenia yang Mengalami Perilaku Kekerasan}

Hasil penelitian ini menunjukkan bahwa beban objektif keluarga saat merawat pasien skizofrenia mayoritas sedang. Hal ini dibuktikan dengan analisa kuesioner atas jawaban responden, keluarga sering menghabiskan uang untuk anggota keluarga yang mengalami gangguan jiwa, waktu keluarga sering terganggu saat bekerja karena ada anggota keluarga yang mengalami gangguan jiwa, dan waktu keluarga terfokus hanya untuk merawat anggota yang mengalami gangguan jiwa. Hasil penelitian Ripangga \& Damaiyanti (2018) di Poliklinik Rumah Sakit Jiwa Atma Husada Mahakam Samarinda, ada hubungan signifikan antara beban keluarga dengan sikap keluarga dalam merawat pasien skizofrenia dengan nilai $\mathrm{r}=0,758$ dan $p$ value $0,00<0,01$. Hasil penelitian Nuraenah, dkk., 2014) bahwa beban keluarga berat (95\%) dalam merawat pasien perilaku kekerasan karena faktor ekonomi sosial sangat mempengaruhi beban keluarga, dimana rata-rata penghasilan keluarga yang minim.

Hasil penelitian ini beban keluarga dengan beban obyektif mayoritas ringan sebanyak 10 responden $(12,7 \%)$. Hal ini dipengaruhi oleh kemudahan keluarga untuk membawa klien kepelayanan kesehatan akan mengurangi beban keluarga dalam merawat, begitu juga sebaliknya, jika pelayanan kesehatan khususnya mental tidak tersedia atau sulit dijangkau akan menyebabkan keadaan paien lebih buruk yang akan menjadi beban bagi keluarga yang merawat (Nuraenah, dkk., 2014). Pada penelitian ini didapatkan juga beban keluarga dengan beban objektif kategori berat sebesar $12,7 \%$ atau sebanyak 10 orang. Hal ini dipengarui oleh status ekomoni responden yang rendah dan jarak tempat tinggal responden jauh dari pelayanan kesehatan jiwa.

Hasil penelitian ini juga menunjukkan bahwa sebanyak 37 responden (46,8\%) adalah wiraswasta dan petani sebanyak 25 responden $(31,6 \%)$. Pekerjaan berhubungan erat dengan sosial ekonomi keluarga yang akan membantu keluarga yang sakit untuk berobat. Hal ini sesuai dengan penelitian Ngadiran (2010) beban obyektif adalah masalah yang berhubungan dengan pelaksanaan perawatan klien, yang 
meliputi; tempat tinggal, makanan, transportasi, pengobatan, keuangan, krisis. Keluarga memerlukan biaya untuk klien di rumah sakit, mengantarkannya berobat. Bahwa anggota keluarga dengan kemampuan ekonomi yang cukup, maka akan beban yang timbul akan lebih sedikit dibanding anggota keluarga yang tidak mampu (Fitrikasari, dkk., 2012). Hal ini akan semakin meningkat jika berlangsung lama.

Peneliti berasumsi bahwa saat merawat pasien skizofrenia yang mengalami perilaku kekerasan keluarga merasa terbebani untuk merawat klien. Hal ini dikarenakan faktor ekonomi keluarga dan jarak yang ditempuh untuk membawa keluarga yang sakit ke pelayanan kesehatan jiwa sangat jauh serta waktu kerja keluarga pun terganggu saat merawat keluarga yang sakit.

\section{Beban Subjektif Keluarga Saat Merawat Pasien Skizofrenia yang Mengalami Perilaku Kekerasan}

Hasil penelitian ini menunjukkan bahwa beban subyektif keluarga saat merawat pasien skizofrenia yang mengalami perilaku kekerasan mayoritas sedang, keluarga merasa terbebani saat merawat keluarga yang mengalami perilaku kekerasan karena mereka merasa tidak berdaya lagi dan putus asa ketika melihat anggota keluarganya yang sakit. Hal ini menunjukkan emosi keluarga yang sedang sehingga beban subyektif keluarga adalah sedang.

Berdasarkan hasil kuesioner yang dibagikan oleh peneliti, didapatkan bahwa sebanyak $70 \%$ keluarga mengatakan bahwa mereka sangat terbebani saat merawat anggota keluarga yang sakit. Kebanyakan respoden mengatakan sering sakit karena merawat pasien, kadang emosi melihat perilaku klein saat dirumah, merasa tidak berdaya, cemas, putus asa, depresi bahkan merasa lelah ketika mengantarkan anggota keluarga yang mengalami gangguan jiwa untuk berobat di pelayanan kesehatan. Menurut Ngadiran (2010) beban subyektif adalah masalah yang berhubungan dengan kehilangan, takut, merasa bersalah, marah dan perasaan negatif lainnya yang dialami oleh keluarga sebagai respon terhadap anggota keluarga yang gangguan jiwa.

Keluarga yang merawat pasien, mengatakan adanya peningkatan beban yang mereka tanggung, baik beban psikologis maupun beban sosial. Beban psikologis yang mereka ungkapkan berupa perasaan bersalah, sedih, marah, takut, cemas, dan gelisah terhadap kondisi pasien. Selain itu,mereka harus menghadapi beban sosial berupa stigma dan reaksi kemarahan dari tetangga dan lingkungan sekitar (Mirza, dkk., 2015). Hasil penelitian yang dilakukan Nuraenah, dkk (2014) bahwa ekspresi emosi keluarga yang tinggi rata-rata memiliki beban yang tinggi jika dibandingkan dengan keluarga yang memiliki ekspresi emosi yang rendah. Ekspresi emosi keluarga yang tinggi sangat dipengaruhi oleh keadaan pasien saat dirawat. Sesuai dengan penelitian Pardede, dkk (2015). Ekspresi emosi keluarga yang tinggi menyebabkan frekuensi kekambuhan penderita skizofrenia makin meningkat.

Keadaan ini terjadi ketika pasien marahmarah, membanting barang dan bahkan memukul orang sehingga keluarga emosi melihat perilaku pasien. Melihat hal tersebut, keluarga merasa sangat terbebani ketika melihat perilaku yang ditunjukkan oleh pasien saat dirawat dirumah.

Peneliti berasumsi bahwa saat merawat pasien skizofrenia yang mengalami perilaku kekerasan keluarga merasa terbebani untuk merawat klien. Hal ini dikarenakan faktor-faktor psikologis seperti kehilangan, kesedihan, frustasi, kecemasan dan malu dalam kondisi sosial yang dialamai anggota keluarga yang sakit.

\section{Koping Keluarga Saat Merawat Pasien Skizofrenia yang Mengalami Perilaku Kekerasan}

Hasil penelitian ini menunjukkan bahwa mayoritas koping keluarga adalah dalam kategori adaptif sebanyak 77 responden $(97,5 \%)$. Hal ini menggabarkan bahwa keluarga sudah memiliki keyakinan atau pandangan yang positif, memiliki keterampilan memecahkan masalah, memiliki keterampilan sosial yang baik dan dukungan sosial yang baik juga, ini dibuktikan dengan analisa kuesioner atas jawaban responden keluarga selalu berusaha melakukan banyak hal terhadap situasi yang terjadi, keluarga selalu mencari solusi atas masalah yang sedang terjadi, keluarga selalu berusaha untuk mendapatkan saran atau bantuan dari orang lain tentang apa yang harus dilakukan dan keluarga juga selalu mengatakan hal baik untuk menghilangkan pikiran buruk dalam menghadapi anggota keluarga yang sakit. Saat merawat anggota keluarga yang sakit, peran dan fungsi keluarga sangat penting dalam menyelesaikan masalah yang dialami oleh pasien. Selain itu anggota keluarga perlu menjadi kuat dan belajar menyembunyikan perasaan dan menguasai ketegangan dalam diri mereka sendiri (Friedman, 2013). 
Dalam menjalankan fungsi keluarga berbagai permasalahan yang dialami oleh keluarga saat merawat anggota keluarga yang sakit, sehingga keluarga merasa sangat terbebani dalam memenuhi kebutuhan keluarga. Pada penelitian ini dibahas dua macam beban keluarga antara lain beban obyektif dan beban subyektif. Pada saat keluarga menanggung beban, keluarga perlu memiliki koping yang adaptif, sehingga keluarga mampu mengahadapi masalah yang mereka hadapi.

Koping keluarga internal merupakan strategi positif dari dalam adaptasi keluarga dalam upaya-upaya pemecahan masalah dalam merawat pasien skizofrenia. Meskipun sumber koping dari dalam (internal) penting, keluarga perlu menghasilkan dan menerima informasi eksternal yang lebih besar. Strategi koping yang dilakukan termasuk mencari informasi, memelihara hubungan aktif dengan komunitas, mengupayakan dukungan sosial dan mencari dukungan spiritual.

Peneliti berasumsi dengan koping keluarga sebagai respon keluarga terhadap situasi yang mengancam baik fisik maupun psikologis, yang dimana keluarga unit terdekat dengan penderita dan sistem pendukung utama yang memberi perawatan langsung pada setiap keadaan sehatsakit klien. sehingga pasien tidak lepas dari perhatian dan bantuan dari keluarga.

\section{Hubungan Beban Objektif dengan Koping Keluarga Saat Merawat Pasien Skizofrenia yang Mengalami Perilaku Kekerasan}

Hasil penelitian didapatkan bahwa Ada hubungan beban obyektif dengan koping keluarga saat merawat pasien skizofrenia yang mengalami perilaku kekerasan. Hasil penelitian ini membuktikan bahwa responden yang memiliki beban keluarga obyektif sedang mayoritas koping keluarga adapatif.

Hal ini sejalan dengan penelitian Suryaningrum \& Wardani (2013) ada hubungan antara beban obyektif dengan kemampuan keluarga merawat pasien perilaku kekerasan di poliklinik Rumah Sakit Marzoeki Mahdi Bogor. Menurut Fontaine (2009) bahwa kemampuan keluarga ditentukan oleh manajemen stres yang produktif. Kelelahan fisik dan emosi selama merawat anggota keluarga dengan gangguan jiwa sering melanda keluarga karena berkurangnya stress tolerance. Dalam penelitian ini manajemen stress keluarga dalam merawat keluarga sudah bagus, itu terlihat dari koping keluarga dalam kategori adaptif $(72,2 \%)$.
Koping keluarga yang baik dapat digambarkan bahwa persepsi keluarga tentang anggota keluarga dengan skizofremia positif. Keluarga dengan anggota keluarga menderita skizofrenia tidak menjadikan beban keluarga tetapi merupakan hal yang harus dihadapi oleh keluarga dalam merawat anggota keluarga yang menderita skizofrenia. Beban obyektif keluarga dalam kategori sedang $(72,2 \%)$ dan ringan $(12,7 \%)$ hal ini dipengaruhi faktor jarak rumah ke tempat pelayanan kesehatan yang jauh dan faktor ekomoni ini tidak membuat koping keluarga menjadi kurang atau maladaptif. Keluarga memiliki keyakinan atau pandangan positif dalam merawat keluarga dengan skizofrenia. Keyakinan menjadi daya sumber psikologis yang sangat penting seperti keyakinan akan nasib (external locus of control) yang mengerahkan individu pada penilaian ketidakberdayaan (helplessness) yang akan menurunkan strategi koping.

Peneliti berasumsi bahwa saat merawat pasien skizofrenia merupakan hal yang harus dihadapi oleh keluarga. Jarak tempuh yang jauh untuk menuju tempat pelayanan kesehatan jiwa dan masalah ekonomi tidaklah membuat koping keluarga menjadi mal adapatif.

\section{Hubungan Beban Subjektif dengan Koping Keluarga Saat Merawat Pasien Skizofrenia yang Mengalami Perilaku Kekerasan}

Hasil penelitian didapatkan bahwa ada hubungan beban obyektif dengan koping keluarga saat merawat pasien skizofrenia yang mengalami perilaku kekerasan di poliklinik Rumah Sakit Jiwa Prof. Dr. M. Ildrem Provsu Medan. Hasil penelitian ini dibuktikan bahwa responden yang memiliki beban keluarga subyektif sedang mayoritas koping keluarga adapatif.

Pada saat merawat pasien skizofrenia keluarga merasa terbebani dikarenakan perilaku yang ditunjukkan oleh pasien saat dirumah sehingga keluarga merasa cemas, stres, tidak berdaya dan putusasa. Melihat hal tersebut keluarga harus mampu mengatasi semua permasalahan yang dialami dalam keluarga. Dalam penelitian ini manajemen stress keluarga dalam merawat keluarga sudah baik, itu terlihat dari koping keluarga dalam kategori adaptif $(60,8 \%)$. Hal ini didukung oleh Friedman (2013) bahwa fungsi internal keluarga merupakan dasar kekuatan keluarga dimana didalamnya keluarga saling mendukung, saling menghargai, dan saling mengasihi antar anggota keluarga.

Dalam penelitian ini dibahas koping keluarga saat merawat pasien skizofrenia. Hasil 
penelitian yang didapatkan koping keluarga adalah adaptif, dimana keluarga sudah mampu menerima keadaan anggota keluarga yang sakit. Hal ini dapat dilihat dari hasil kuesioner yang diisi oleh responden yang mengatakan bahwa keluarga berusaha melakukan banyak hal terhadap situasi yang sedang dihadapi, mencari solusi atas masalah yang sedang terjadi dan selalu menerima kenyataan yang terjadi.

Koping merupakan proses yang dilalui oleh individu dan menyelesaikan situasi stres yang dihadapi. Koping keluarga yang baik menggambarkan bahwa persepsi keluarga tentang anggota keluarga dengan skizofenia adalah positif. Keluarga memberikan dukungan sosial, rasa empati, penerimaan, dan untuk tidak putus asa serta terus berusaha untuk merawat anggota keluarga yang sakit. Dalam penelitian ini juga didapatkan beban subjektif berat $31,6 \%$, hal ini mengindikasikan bahwa sebagian responden masih belum mampu untuk mengatasi stres yang mereka alami.

Hal ini terjadi karena sebagian responden mengatakan bahwa saat merawat pasien skizofrenia masih belum bisa menerima keadaan yang dialami oleh pasien, tidak pernah mendapatkan dukungan emosi dari orang lain dan bahkan mereka mengatakan sudah menyerah dalam mengahadapi kesulitan-kesulitan yang

\section{DAFTAR PUSTAKA}

Benson, L. A., Sevier, M., \& Christensen, A. (2013). The impact of behavioral couple therapy on attachment in distressed couples. Journal of Marital and Family Therapy, 39(4), 407-420. https://doi.org/10.1111/jmft.12020

Fitrikasari, A., Kadarman, A., \& Sarjana, W. (2012). Gambaran Beban Caregiver Penderita Skizofrenia di Poliklinik Rawat Jalan RSJ Amino Gondohutomo Semarang. Medica Hospitalia: Journal of Clinical Medicine, 1(2). Doi: https://doi.org/10.36408/mhjcm.v1i2.56

Fontaine, K. L. (2009). Mental health nursing. Prentice Hall.

Friedman. L. M. (2013). Keperawatan Keluarga. Yogyakarta: Gosyen Publishing

Jenkins, J. H., \& Schumacher, J. G. (2018). Family burden of schizophrenia and depressive illness. British Journal of Psychiatry, 174(01), 31-38. Doi: https://doi.org/10.1192/bjp.174.1.31

Kementerian Kesehatan RI. (2018). Hasil Utama Riskesdas Tahun 2018. Badan Penelitian sudah terjadi. Melihat keadaan tersebut, koping keluarga pun masih belum efektif. Hasil penelitian ini juga didapatkan beban subyektif ringan sebesar $7,6 \%$, hal ini mengindikasikan bahwa keluarga tidak merasa terbebani saat merawat pasien skizofrenia yang mengalami perilaku kekerasan.

Peneliti berasumsi bahwa keluarga yang memiliki koping keluarga adaptif dapat mengurangi beban keluarga subyektif, sehingga keluarga mampu dan memberikan asuhan dalam merawat anggota keluarga lebih baik.

\section{SIMPULAN}

Beban objektif keluarga saat merawat pasien skizofrenia yang mengalami perilaku kekerasan mayoritas sedang, Beban subjektif keluarga saat merawat pasien skizofrenia yang mengalami perilaku kekerasan mayoritas sedang, Koping keluarga saat merawat pasien skizofrenia yang mengalami perilaku kekerasan mayoritas adaptif. Ada hubungan signifikan antara beban objektif keluarga dengan koping saat merawat pasien yang mengalami perilaku kekerasan dan ada hubungan signifikan antara beban keluarga subjektif dengan koping saat merawat pasien yang mengalami perilaku kekerasan. dan Pengembangan Kesehatan Kementerian Kesehatan Republik Indonesia. https://www.kemkes.go.id/resources/down load/info-terkini/hasil-riskesdas-2018.pdf

Mantovani, L. M., Ferretjans, R., Marçal, I. M., Oliveira, A. M., Guimarães, F. C., \& Salgado, J. V. (2016). Family burden in schizophrenia: the influence of age of onset and negative symptoms. Trends in psychiatry and psychotherapy, 38(2), 9699. https://doi.org/10.1590/2237-60892015-0082.

Mirza, M., Raihan, R., \& Kurniawan, H. (2015). Hubungan Lamanya Perawatan Pasien Skizofrenia Dengan Stres Keluarga. Jurnal Kedokteran Syiah Kuala, 15(3), 179-189. http://www.jurnal.unsyiah.ac.id/JKS/article /view/3669

Ngadiran, A. (2010). Studi fenomena Pengalaman Keluarga Tentang Beban dan sumber Dukungan Keluarga Dalam Merawat Klien Dengan Halusinasi. [Tesis]. Depok: Universitas Indonesia. 
Nuraenah, N., Mustikasari, M., \& Putri, Y. S. E. (2014). Hubungan dukungan keluarga dan Beban Keluarga dalam merawat anggota dengan riwayat perilaku kekerasan di Rs. Jiwa Islam Klender Jakarta Timur 2012. Jurnal Keperawatan Jiwa, 2(1), 41-50. https://doi.org/10.26714/jkj.2.1.2014.41-50

Nuttall, A. K., Thakkar, K. N., Luo, X., Mueser, K. T., Glynn, S. M., Achtyes, E. D., \& Kane, J. M. (2019). Longitudinal associations of family burden and patient quality of life in the context of firstepisode schizophrenia in the RAISE-ETP study. Psychiatry research, 276, 60-68. https://doi.org/10.1016/j.psychres.2019.04. 016

Patricia, H., Rahayuningrum, D. C., \& Nofia, V. R. (2019). Hubungan Beban Keluarga Dengan Kemampuan Caregiver Dalam Merawat Klien Skizofrenia. Jurnal Kesehatan Medika Saintika, 10(2), 45-52. http://dx.doi.org/10.30633/jkms.v10i2.449

Pardede, J. A., Sirait, D., Riandi, R., Emanuel, P., \& Laia, R. (2016). Ekspresi Emosi Keluarga Dengan Frekuensi Kekambuhan Pasien Skizofrenia. Idea Nursing Journal, 7(3), 53-61.

http://www.jurnal.unsyiah.ac.id/INJ/article /view/6446

Pardede, J. A., Siregar, L. M., \& Hulu, E. P. (2020). Efektivitas Behaviour Therapy Terhadap Risiko Perilaku Kekerasan Pada Pasien Skizofrenia Di Rumah Sakit Jiwa Prof. Dr. Muhammad Ildrem Provsu Medan. Jurnal Mutiara Ners, 3(1), 8-14.
http://114.7.97.221/index.php/NERS/articl e/view/1005

Ripangga, F., \& Damaiyanti, M. (2018). Hubungan Beban Keluarga Dengan Sikap Keluarga Dalam Merawat Pasien Skizofrenia Di Poliklinik Rumah Sakit Jiwa Atma Husada Mahakam Samarinda. [Skripsi]. Samarinda: Universitas Muhammadiyah Kalimantan Timur. https://dspace.umkt.ac.id/handle/463.2017/ 932

Stuart, G. W. (2014). Principles and practice of psychiatric nursing-e-book. Elsevier Health Sciences.

Suryaningrum, S., \& Wardani, I. Y. (2013). Hubungan Antara Beban Keluarga Dengan Kemampuan Keluarga Merawat Pasien Perilaku Kekerasan Di Poliklinik Rumah Sakit Marzoeki Mahdi Bogor. Jurnal Keperawatan Jiwa, 1(2). https://doi.org/10.26714/jkj.1.2.2013.\%25p

Suryenti, V. (2017). Dukungan Dan Beban Keluarga Dengan Kemampuan Keluarga Merawat Pasien Resiko Perilaku Kekerasan Di Klinik Jiwa Rumah Sakit Jiwa Provinsi Jambi Tahun 2017. Jurnal Psikologi Jambi, 2(2), 39-46. https://www.online-journal.unja.ac. id/jpj/article/view/4795

Townsend, M. C., \& Morgan, K. I. (2017). Psychiatric mental health nursing: Concepts of care in evidence-based practice. FA Davis.

WHO. (2019). Schizophrenia. https://www.who.int/news-room/factsheets/detail/schizophrenia 